\title{
Advanced Oxidation Processes (AOPs) alternative methods for degradation of toxic pollutants from wastewater
}

\author{
INES NITOI, LUCIAN ALEXANDRU CONSTANTIN, IONUT CRISTEA, MIRELA ALINA \\ CONSTANTIN
}

National Research and Development Institute for Industrial Ecology ECOIND Bucharest, 71-73 Drumul Podul Dambovitei, 060652, Bucharest, Romania

*Corresponding author (e-mail): ines.nitoi@incdecoind.ro

The degradation of some toxic pollutants like chlorobenzenes, nitrobenzene and 4-chloroaniline in various advanced oxidation system such as: $\mathrm{UV} / \mathrm{H}_{2} \mathrm{O}_{2}, \mathrm{UV}$-VIS/Fe-TiO $\mathrm{T}_{2}$ and $\mathrm{UV}$-VIS/TiO $/ \mathrm{H}_{2} \mathrm{O}_{2}$ were studied. The influence of working conditions $\left(\mathrm{pH}_{0}, \mathrm{H}_{2} \mathrm{O}_{2}\right.$ dose, photocatalyst dose, pollutant initial concentration and irradiation time) on pollutant degradation rate constant and efficiency were investigated. For any studied advanced oxidation systems, pollutant degradation followed a pseudo first order kinetics. The degradation pathway of chlorinated and nitro aromatic pollutants includes initial ${ }^{\circ} \mathrm{OH}$ radicals attack to aromatic ring with hydroxylated intermediates formation, followed by their step by step oxidation up to carboxylic acids. Inorganic ions like $\mathrm{Cl}^{-}, \mathrm{NO}_{3}{ }^{-}, \mathrm{NH}_{4}^{+}$ are also formed as mineralization products.

Keywords: chlorobenzene, nitrobenzene, 4-chloroaniline, photocatalyst, $\mathrm{H}_{2} \mathrm{O}_{2}$, kinetics and pathway degradation

Water is essential for life and although approximately $70 \%$ of the terrestrial area is covered with water, only a small fraction $(2.5 \%)$ is freshwater compatible with terrestrial life [1]. This low stock of available freshwater is being accompanied by an increase of human consumption as consequence of demographic growth, industry demand and improved living conditions. It is even estimated that in some world regions, the water use has risen twice faster than the human population. In fact, half of the European countries are already facing water stress and it is estimated that within the next 50 years more than $40 \%$ of the population worldwide will face water stress or scarcity [13]. All this together represents a solemn inducement to achieve sustainable management options of the water resources [1]. The human being plays a major role on the issue of pollutants released in wastewater, which includes heavy metals, antibiotics, pesticides, polyaromatic hydrocarbons, halogenated compounds, and endocrine disruptors, most of them known as emerging pollutants $[4,5]$.

As conventional methods applied in wastewater treatment are limited and their associated operational and capital costs are high, the issue of emerging pollutants removal from environment is not completely solved [6].

The results achieved in latest years showed that
Advanced Oxidation Processes (AOPs) based on photochemical and photocatalytic approaches seem to be very promising as viable alternatives for appliance on wastewater treatments of different sources.

These approaches allow the transformation of pollutants into less toxic substances and/or with structural features that are more biodegradable [7] and are based on the combination of oxidizing agents with an appropriated catalyst and/or light $[7,8]$.

These processes may be of particular interest for the effluent's treatment containing highly toxic compounds like emerging pollutants, and for which the biological processes might not be appropriate [7].

AOPs involves specific chemical reactions that generate highly reactive chemical oxidizing species which are capable to oxidize and mineralize almost any organic molecule, even the most recalcitrant molecules to $\mathrm{CO}_{2}$ and inorganic ions [7-10]. These processes generally involve use of light. The degradation by photochemical reactions of organic pollutants present in water media can be achieved, but the degradation degree is dependent on their chemical structure [11]. The AOPs efficiency tends to be maximized when the use of an appropriate catalyst is considered. Although there are different oxidative systems, the 
production of powerful oxidizing agents, such as hydroxyl radical $(\mathrm{HO} \bullet)$, is the main objective of most AOPs, since these oxidizing agents react very fast [9]. Also, their nonselective attack to organic compounds is a useful attribute for wastewater treatment and a potential solution of pollution issues. These oxidizing species can act at various levels such as hydrogen abstraction from aliphatic carbon, electron transfer or by addition to double bonds and aromatic rings $[7,10,12]$. This type of reactions generates organic radicals as intermediates, which then undergo additional reactions, ending in final products [13]. The hydroxyl radicals can react with a vast range of organic compounds at rates often nearby the diffusion-controlled limit $[7,14,15]$.

The versatility of the AOPs is likewise enhanced by the fact that exist different ways to produce hydroxyl radicals, facilitating the compliance with specific treatment requirements in accordance with effluent's characteristics $[9,10]$. The AOPs as a photochemical process can occur according two main ways: homogeneous (when both reactants and pollutants are in the same phase) and heterogeneous systems (when reactants and catalysts are in different phases. In general, photocatalytic process can be conducted under visible-light irradiation either with or without the presence of UV radiation [7]. The region of the electromagnetic spectrum used to the photochemical process is dependent on the reactant/catalyst absorption features [10].

Methods based on ultraviolet light (UV), and $\mathrm{H}_{2} \mathrm{O}_{2}$ use the photolysis of this oxidizing agent to produce hydroxyl radicals $[9,10]$. Additionally, other applied methods like heterogeneous photocatalysis, are based on the use of a wide-band-gap metal oxide semiconductor without or with addition of $\mathrm{H}_{2} \mathrm{O}_{2}$ to retardation of electrons-holes recombination process which assures enhance of catalyst photoactivity, respectively, and irradiation with UV-VIS light. Both processes are of interest due to fact that the homogenous system has advantages of hydrogen peroxide which is easy to handle and environmentally safe, since in the heterogeneous system sunlight can be used, especially for doped semiconductors, which brings a set of economic benefits.

There are several types of AOPs used in WWTPs, each one of them can be effective in certain types of wastewater and operational conditions. The AOPs which will be reviewed in the following subsections are hydrogen peroxide assisted photocatalysis $\left(\mathrm{UV} / \mathrm{H}_{2} \mathrm{O}_{2}\right)$ and photocatalytic process in the following systems: $\mathrm{UV} / 0.5 \mathrm{Fe}-\mathrm{TiO}_{2}$ and $\mathrm{UV} / \mathrm{TiO}_{2} / \mathrm{H}_{2} \mathrm{O}_{2}$. Target studied pollutants have been halogenated aromatic compounds like chlorobenzenes (CB) and 4-chloraniline(4CLA) and nitro aromatic derivative, respectively nitrobenzene(NB), all of them included in the emerging compounds lists.

\section{EXPERIMENTAL PART}

The pollutants photodegradation was carried out in a Laboratory-UV-Reactor system (Heraeus) with medium-pressure mercury lamps which emit in the range of 200-280 nm (UVC) (TQ150 lamp), and respectively in the range 300-500nm (UV-VIS) (TQ150-Z2).

The lamp equipped with a quartz cooling jacket was immersed in the center of the reactor containing the pollutant solution. The photon's flow of the emitted radiations was determined by ferrioxalate actinometry and values $\mathrm{I}_{0}=(5.3$ 6) $\times 10^{-6}$ einstein $\mathrm{s}^{-1}$ were found.

Solutions with $\mathrm{CB}$ concentrations between $0.1 \times 10^{-3}-1.8 \times 10^{-3} \mathrm{M}$ and of $\mathrm{H}_{2} \mathrm{O}_{2}$ between $0.3 \times 10^{-2}-9 \times 10^{-2} \mathrm{M}$, which correspond to molar ratio $\left[\mathrm{H}_{2} \mathrm{O}_{2}\right] /[\mathrm{CB}]$ in the range $5 / 1-50 / 1$, were used in peroxide assisted photolysis experiments. In the case of photocalysis experiments in UV-VIS/metal doped $\mathrm{TiO}_{2}$, solutions with (0.37-8.45) x $10^{-4} \mathrm{M} \mathrm{NB}$ content were photo-oxidized in the following working conditions: $\mathrm{pH}=4-10$; photo catalyst dose $=50$ $500 \mathrm{mg} / \mathrm{L}$; irradiation time $=30-240$ minutes. Experiments performed in $\mathrm{UV} / \mathrm{TiO}_{2} / \mathrm{H}_{2} \mathrm{O}_{2}$ system were conducted with various concentration of $\mathrm{H}_{2} \mathrm{O}_{2}$ between $1 \times 10^{-4}-1 \times 10^{-2} \mathrm{M}$, at fixed $\mathrm{pH}=4, \mathrm{TiO}_{2}$ dose $150 \mathrm{mg} / \mathrm{L}$ and $1.42 \times 10^{-3} \mathrm{M} 4-$ CLA concentration. Prior to irradiation, the required powder photocatalyst dose was added to samples, and the solutions were bubbled with air $(50 \mathrm{~L} /$ hour) for $30 \mathrm{~min}$ in the dark for both photocatalytic systems studied. The sample's $\mathrm{pH}$ was controlled using a Consort C532 pH-meter. The solution within the reactor was homogenized continuously using a magnetic circulation pump.

The concentration of $\mathrm{CB}$ and NB were determined via Gas Chromatography couple 
with flame ionization detector (GC-FID) using an Agilent 6890N equipment. The concentration of 4-CLAwas analyzed by GC-MS using an Agilent 7890A Gas Chromatograph with 5\% phenyl methyl siloxane capillary column coupled with an Agilent 240 Ion Trap Mass Spectrometer.

GC-MS screening method was applied for qualitative identification of 4-CLA degradation intermediates, by coupling Agilent 6890N with DB-5MS capillary column to mass spectrometer 5975 BinterXL with electron ionization $(70 \mathrm{eV})$. Total Organic Carbon concentration was determined using an MULTI N/C 3000 Analyzer (Analytik Jena).

Mineralization products $\left(\mathrm{Cl}^{-}, \mathrm{NH}_{4}{ }^{+}, \mathrm{NO}_{3}{ }^{-}\right)$were determined using aDionex ICS-3000 Ion Chromatograph, with separate anions and cations columns and suppressed conductivity detectors.

All experiments were duplicated to assure data quality.

The following reagents were used: chlorobenzene (Merck) of 99wt. \% purity;nitrobenzene (Merck) of 99wt. \% purity;4- chloroaniline (Aldrich) of 99wt.\% purity; $\mathrm{TiO}_{2}$ (Merck) powder with 80 wt.\% anatase; metal - doped $(0.5-5 \mathrm{wt} \% \mathrm{Fe}, \mathrm{Ni}, \mathrm{Co})$ $\mathrm{TiO}_{2}$ powders synthesizedby alkoxide route of sol-gel method (Institute of Physical Chemistry); hydrogen peroxide (Merck) reagentgrade 35wt. \% solution; $\mathrm{Na}_{2} \mathrm{SO}_{3}$ (Merck) $98 \mathrm{wt} . \%$ purity used for the removal of unconsumed $\mathrm{H}_{2} \mathrm{O}_{2}$ from irradiated samples; disodium ethylenediaminetetracetate (Sigma Aldrich) of 98 wt.\% purity, isopropyl alcohol (J.T.Baker) of $99.7 \mathrm{wt} \%$ purity and 1,4benzoquinone (Sigma Aldrich) of 99.5 wt.\% purity utilised as holes $\left(\mathrm{h}^{+}\right)$, hydroxyl radical $\left({ }^{\circ} \mathrm{OH}\right)$ and superoxide radical $\left(\mathrm{O}_{2}{ }^{\circ}\right)$ scavengers; $\mathrm{NaOH}$ (Merck) 99wt. \% purity and $\mathrm{H}_{2} \mathrm{SO}_{4}$ $1 \mathrm{~N}$ (Merck)were used for $\mathrm{pH}$ correction; nhexane (UniSolv) GC grade used for pollutants and intermediates extraction from water samples; anhydrous $\mathrm{Na}_{2} \mathrm{SO}_{4}$ (Merck) 99wt. \% purity used for removal of water traces from nhexane extracts; KI (Merck) 99wt. \% purity and $\mathrm{Na}_{2} \mathrm{~S}_{2} \mathrm{O}_{3} 0.1 \mathrm{~N}$ (Merck) used for iodometric determination of $\mathrm{H}_{2} \mathrm{O}_{2}$.

\section{RESULTS AND DISCUSSION \\ $\mathrm{H}_{2} \mathrm{O}_{2}$ assisted photolysis of $\mathrm{CB}$}

This process is effected by irradiating the pollutant solution containing $\mathrm{H}_{2} \mathrm{O}_{2}$ with UV light having wavelengths $<280 \mathrm{~nm}$, that causes the homolytic cleavage of $\mathrm{H}_{2} \mathrm{O}_{2}$ [16].

$$
\mathrm{H}_{2} \mathrm{O}_{2}+\mathrm{h} v \rightarrow 2^{\circ} \mathrm{OH}
$$

In aqueous solution, the cage effect of water molecules lowers the primary quantum yield to 0.5 :

$$
\begin{gathered}
2 \mathrm{AB}+\mathrm{h} v \rightarrow 2\left(\mathrm{~A}^{\bullet}------\mathrm{B}^{*}\right) \rightarrow \mathrm{A}^{\bullet}+\mathrm{B}^{\bullet} \\
\downarrow \\
\mathrm{AB}
\end{gathered}
$$

Since $\mathrm{H}_{2} \mathrm{O}_{2}$ itself is attacked by $\mathrm{OH}$ radicals

$$
\begin{aligned}
& 2\left(\mathrm{H}_{2} \mathrm{O}_{2}+{ }^{\circ} \mathrm{OH}\right) \rightarrow 2 \mathrm{H}_{2} \mathrm{O}+2 \mathrm{HO}_{2}{ }^{\circ} \\
& 2 \mathrm{HO}_{2} \rightarrow \mathrm{H}_{2} \mathrm{O}_{2}+\mathrm{O}_{2}
\end{aligned}
$$

the overall quantum yield becomes one. The major drawback of the process is due to the small molar extinction coefficient of $\mathrm{H}_{2} \mathrm{O}_{2}$ which is only $18.6 \mathrm{M}^{-1} \mathrm{~cm}^{-1}$ at $254 \mathrm{~nm}$, only a relative small fraction of incident light is therefore exploited [17].

Various studies have been carried out to investigate the effectiveness of AOP technologies toward the degradation of a wide variety of halo aromatic compounds [18-21]. These studies revealed that in a $\mathrm{UV} / \mathrm{H}_{2} \mathrm{O}_{2}$ system, degradation process rates were strongly affected by the operating conditions like $\mathrm{H}_{2} \mathrm{O}_{2}$ /pollutant molar ratio, intensity of UV radiation, reactor geometry, and irradiation time $[22,23]$. Some authors which investigated degradation of chlorobenzene in $\mathrm{UV} / \mathrm{H}_{2} \mathrm{O}_{2}$ system showed that depending upon the irradiation time, various intermediates were formed such as chlorophenol, different isomers of chlorobiphenyl and dichlorobiphenyl [24]. They observed the $\mathrm{pH}$ decrease during the irradiation and attributed it to the release of chlorine as $\mathrm{HCl}$ in the solution. The investigation of formed intermediates was also carried out by other authors [25-27], which reported low molecular weight oxygenated compounds as oxidation products. At longer enough irradiation times (hours), the subsequent degradation of these compounds may lead up to mineralization [24]. It was reinvestigated the photodegradation of $\mathrm{CB}$ in $\mathrm{UV} / \mathrm{H}_{2} \mathrm{O}_{2}$ system in order to bring new kinetic information which support degradation mechanism of $\mathrm{CB}$ reported in literature [24,27,28]. 
Kinetics of $\mathrm{CB}$ degradation in $\mathrm{UV} / \mathrm{H}_{2} \mathrm{O}_{2}$ system and $\mathrm{H}_{2} \mathrm{O}_{2}$ concentration influence

The photodegradation kinetic of $\mathrm{CB}$ in the presence of $\mathrm{H}_{2} \mathrm{O}_{2}$, at $\mathrm{pH}=7$, under $\mathrm{UV}$ irradiation verified a pseudo-first-order reaction rate with respect to the pollutant and chloride ion, one of the mineralization final product [28]. Figure 1 presents the kinetics monitored at $\mathrm{pH}=7$, for a sample with an initial $\mathrm{CB}$ concentration of $1.8 \times 10^{-3} \mathrm{M}$ at various $\mathrm{H}_{2} \mathrm{O}_{2}$ concentrations corresponding to a molar ratio of $\left[\mathrm{H}_{2} \mathrm{O}_{2}\right] /[\mathrm{CB}]$ between 0/1-50/1.

Fig. 1. The pseudo-first-order kinetics at various $\mathrm{H}_{2} \mathrm{O}_{2}$ concentration of

a) $\mathrm{CB}$ degradation and b) $\mathrm{Cl}^{-}$formation
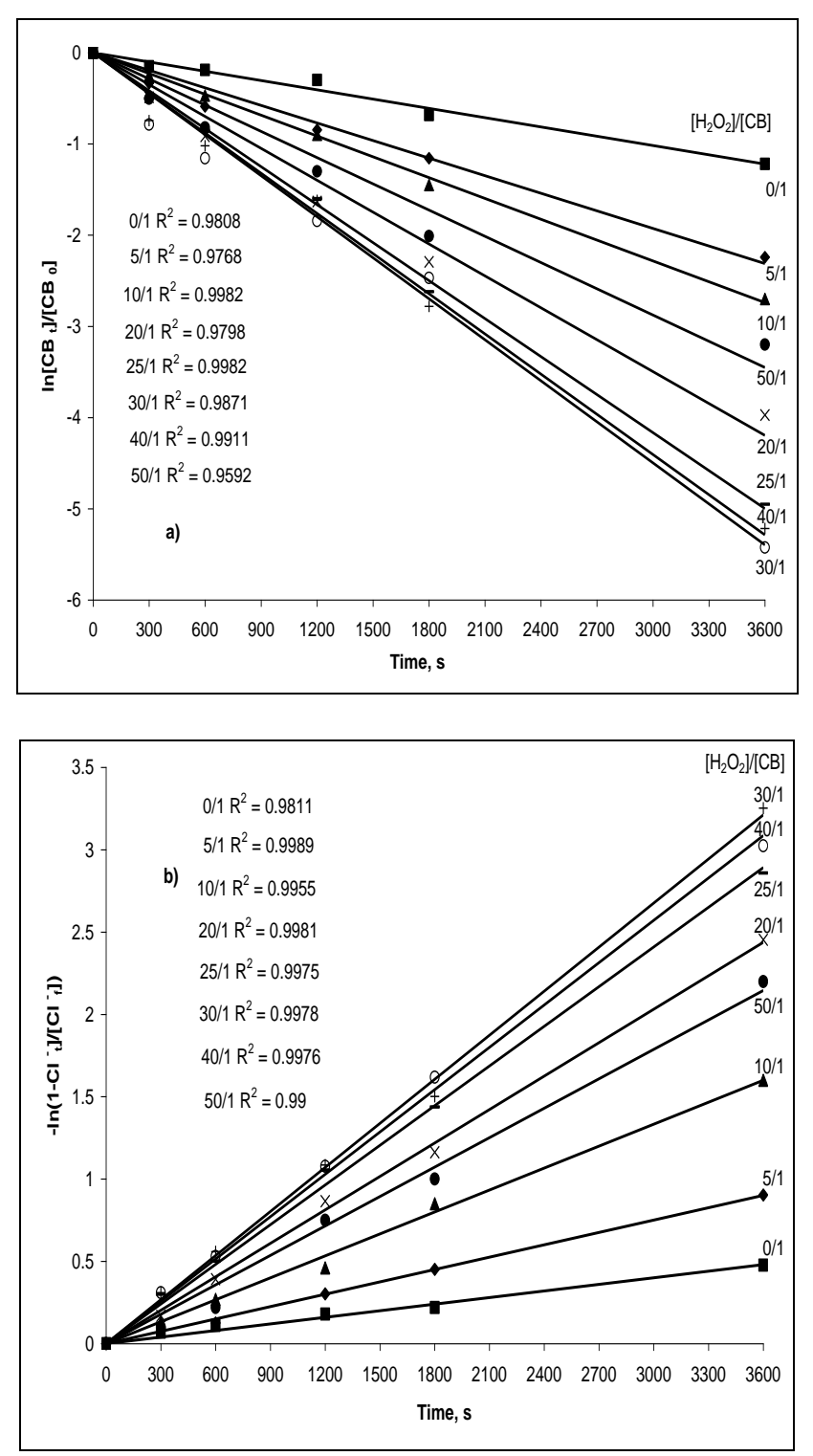

Using the slopes of these straight-lines the rate constants $\mathrm{k}_{\mathrm{CB}}$ and $\mathrm{k}_{\mathrm{Cl}}{ }^{-}$were calculated. In Figure 2 there is presented the evolution of the rate constants versus the hydrogen peroxide concentration.

It is observed that values of $\mathrm{k}_{\mathrm{Cl}}$-are always lower than values of $k_{C B}$, suggesting that the $\mathrm{Cl}^{-}$ liberation does not take place at the same time with the attack of $\bullet \mathrm{OH}$ radicals on $\mathrm{CB}$ molecules. In a first stage chlorinated organic intermediates are formed, which are further releasing chlorine as $\mathrm{Cl}^{-}$ion. In the range of low $\mathrm{H}_{2} \mathrm{O}_{2}$ concentration the both rate constants increase linearly with $\mathrm{H}_{2} \mathrm{O}_{2}$ concentration. On the contrary, at high $\mathrm{H}_{2} \mathrm{O}_{2}$ concentration, these rate constants decrease due to the fact that $\bullet \mathrm{OH}$ radicals are scavenged by the excess of $\mathrm{H}_{2} \mathrm{O}_{2}$. Between these two ranges $\mathrm{k}_{\mathrm{CB}}$ and $\mathrm{k}_{\mathrm{Cl}}{ }^{-}$reach their maximum values $15 \times 10^{-4} \mathrm{~s}^{-1}$ and $9 \times 10^{-4} \mathrm{~s}^{-1}$, respectively, for a short interval of $\mathrm{H}_{2} \mathrm{O}_{2}$ concentration $\left(5.4 \times 10^{-2}-7.2 \times 10^{-2} \quad \mathrm{M}\right)$ corresponding to a $\left[\mathrm{H}_{2} \mathrm{O}_{2}\right] /[\mathrm{CB}]$ molar ratio $30 / 1-$ $40 / 1$. The extrapolation of the linear part leads to rate constants values near to those experimentally obtained in the absence of photosensitizer, via $\mathrm{CB}$ direct photolysis.

Therefore, this behavior can be described by the kinetic equation: $\mathrm{k}_{\mathrm{CB}}=\mathrm{k}_{0}+\mathrm{k} \cdot \mathrm{OH}\left[\mathrm{H}_{2} \mathrm{O}_{2}\right]$, in which $\mathrm{k}_{\mathrm{CB}}$ is the rate constant of $\mathrm{CB}$ degradation determined for various initial $\mathrm{H}_{2} \mathrm{O}_{2}$ concentrations, $\mathrm{k}_{0}$ is the rate constant of $\mathrm{CB}$ photolysis and $\mathrm{k} \cdot \mathrm{OH}$ the second-order rate constant of $\mathrm{CB}$ oxidation by $\mathrm{OH}$ radicals. In Fig. 2 the first linear part represents in fact the plot of before mentioned kinetic equation. A similar equation is valid also for $\mathrm{Cl}^{-}$formation. Some other researchers [24] using similar molar ratio $\left[\mathrm{H}_{2} \mathrm{O}_{2}\right] /[\mathrm{CB}]$ than in our experiments found that the straight-line obtained obeys equation: $\mathrm{k}_{\mathrm{CB}}=$ $\mathrm{k} \cdot \mathrm{OH}\left[\mathrm{H}_{2} \mathrm{O}_{2}\right]$, which shows that only $\mathrm{H}_{2} \mathrm{O}_{2}$ mediated degradation takes place in their irradiated system. However, a similar behavior of the system to that we reported was presented by the same authors in their earlier work, but it was not explained. We consider that the contribution of direct photolysis to $\mathrm{CB}$ degradation is due to the manipulation of the samples at the room light before the irradiation in the photo reactor. 


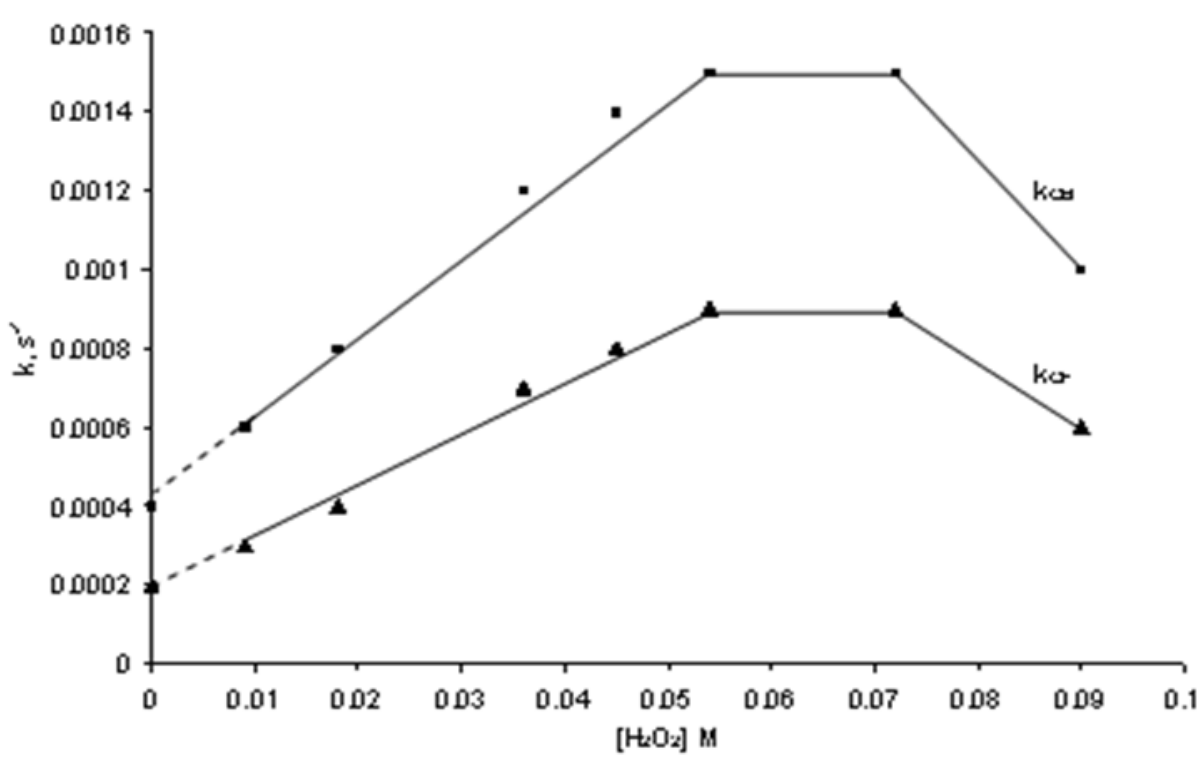

Fig.2. The influence of $\mathrm{H}_{2} \mathrm{O}_{2}$ concentration on the rate constants $\mathrm{k}_{\mathrm{CB}}$ and $\mathrm{k}_{\mathrm{Cl}^{-}}$.

\section{Reaction mechanism}

Many scientists studied the photodegradation of $\mathrm{CB}$ in various experimental conditions, like photolysis, $\mathrm{UV} / \mathrm{H}_{2} \mathrm{O}_{2}, \mathrm{UV} / \mathrm{O}_{3}, \mathrm{UV} / \mathrm{TiO}_{2}$ but only some of them analyzed the systems in order to obtain information on the reaction mechanism $[24,27,29]$. We tried to correlate these data with our results to obtain a general plausible reaction mechanism. This includes $\mathrm{H}_{2} \mathrm{O}_{2}$ photolysis under $\mathrm{UVC}$ irradiation and generation of $\bullet \mathrm{OH}$ radicals which by addition to the double bound, or by hydrogen abstraction attacks the $\mathrm{CB}$ leading to various intermediates [30], the majority being hydroxylated aromatic compounds. Using GSMS analysis, some authors identified chlorophenol, chlorobiphenyl and dichlorobiphenyl [24]. Other authors studding the $\mathrm{CB}$ degradation in $\mathrm{UV} / \mathrm{TiO}_{2}$ systemrevealed that $\mathrm{o}$ - and $\mathrm{p}$-chlorophenol are further oxidized to hydroquinone and catechol [29]. Using flash photolysis/HPLC technique for the degradation of chlorophenol in the presence of $\mathrm{H}_{2} \mathrm{O}_{2}$, have been put in to evidence the same hydroxylated compounds [27]. It has also been shown that increase of $\mathrm{H}_{2} \mathrm{O}_{2}$ concentration changes the product distribution, catechol concentration drop in the favor of hydroquinone and 1,2,4-threehydroxybenzene. The formation of these unchlorinated intermediates agrees with our results which show the total liberation of the organic bound chlorine as $\mathrm{HCl}$, during irradiation. On the other hand, our finding that $\mathrm{k}_{\mathrm{CB}}>\mathrm{k}_{\mathrm{Cl}}{ }^{-}$demonstrates that $\mathrm{Cl}^{-}$ions liberation does not take place simultaneously with the attack of $\cdot \mathrm{OH}$ radicals on $\mathrm{CB}$, but in a further stage, oxidizing the chlorophenols to hydroquinone and three hydroxibenzene. According to our studies, formed intermediates compete with $\mathrm{CB}$ for $\bullet \mathrm{OH}$ radicals consumption as experimental results are emphasizing by the rate constant values. The rate constants values decrease with an increase in the initial $\mathrm{CB}$ concentration, at constant $\left[\mathrm{H}_{2} \mathrm{O}_{2}\right] /[\mathrm{CB}]$ molar ratio. The before cited authors [27] reported that hydroquinone is oxidized to benzoquinone which is cleaved in muconic acid and then under -OH radical attack leads to maleic, fumaric and oxalic acids. In the favor of this presumption we have a qualitative argument: by the appearance of a reddish-brown color, characteristic to benzoquinone, which under prolonged exposure time bleaches due to carboxylic acids formation. The presence of many stable intermediates is justified by the low removal yield of total organic carbon (TOC) of about $14 \%$, determined after irradiation, in our experiments [28].

\section{Photocatalytic pollutant degradation}

These processes use a semiconductor metal oxide as catalyst and oxygen as oxidizing agent [31]. Many catalysts have been so far tested, although only $\mathrm{TiO}_{2}$ in the anatase form seems to havethe most interesting attributes such as high stability, good performance and low cost [32, 33]. The initiating step in the photocatalytic process is the absorption of the radiation with the formation of electron-hole pairs:

$$
\mathrm{TiO}_{2}+\mathrm{h} v \rightarrow \mathrm{e}^{-}+\mathrm{h}^{+}
$$


The considerable reducing power of formed electrons allows them to reduce some metals and dissolved oxygen with the formation of the superoxide radical ion $\mathrm{O}_{2}{ }^{--}$whereas remaining holes are capable of oxidizing adsorbed $\mathrm{H}_{2} \mathrm{O}$ or $\mathrm{OH}^{-}$to reactive ${ }^{\circ} \mathrm{OH}$ radicals:

$$
\begin{aligned}
& \mathrm{TiO} 2\left(\mathrm{~h}^{+}\right)+\mathrm{H}_{2} \mathrm{O}_{\mathrm{ad}} \rightarrow \mathrm{TiO}_{2}+{ }^{\circ} \mathrm{OH}_{\mathrm{ad}}+\mathrm{H}^{+} \\
& \mathrm{TiO}_{2}\left(\mathrm{~h}^{+}\right)+\mathrm{OH}^{-} \text {ad } \rightarrow \mathrm{TiO}_{2}+{ }^{\circ} \mathrm{OH}_{\mathrm{ad}}
\end{aligned}
$$

These reactions are of great importance in oxidative degradation processes due to the high concentration of $\mathrm{H}_{2} \mathrm{O}$ and $\mathrm{OH}^{-}$adsorbed on the catalyst particle surface.

Some adsorbed substrate can be directly oxidized by electron transfer:

$$
\mathrm{TiO}_{2}\left(\mathrm{~h}^{+}\right)+\mathrm{RX}_{\mathrm{ad}} \rightarrow \mathrm{TiO}_{2}+\mathrm{RX}_{\mathrm{ad}}{ }^{+}
$$

Unfortunately, a significant part of electron-hole pairs recombine thus reducing the quantum yield of photocatalytic process. In the most part of the works devoted to the photocatalysis the possible exploitation of the wavelengths of the solar spectrum is stressed. However, this is only partially true since the overlapping between the absorption spectrum of $\mathrm{TiO}_{2}$ and that of the sun at ground is rather poor [33]. Intensive researches are carried out worldwide to obtain modified (doped) $\mathrm{TiO}_{2}$ with broader absorption spectrum and characterized by higher quantum yield.

Another strategy for improving the photocatalytic activity consists of inhibiting $\mathrm{e}^{-}$ $/ h^{+}$recombination by addition of other (irreversible) electron acceptors to the reaction. Outstanding enhancement of the rate of degradation of various organic contaminants through the use of inorganic peroxides has been demonstrated [34,35]. Beside increasing of the number of trapped e- in the e-/h+ pairs and, consequently, avoid their recombination, peroxides addition could have also several different effects: - generation of more ${ }^{\circ} \mathrm{OH}$ and other oxidizing species; $\bullet$ increase the oxidation rate of intermediate compounds; - avoiding problems caused by a low $\mathrm{O}_{2}$ concentration.

It must be mentioned here that in highly toxic wastewater where degradation of organic pollutants is the major concern, the addition of an inorganic anion to enhance the organic degradation rate may often be justified.

For better results, these additives should fulfill the following criteria: dissociate into harmless by-products and lead to the formation of ${ }^{\circ} \mathrm{OH}$ or other oxidizing agents. There is another advantage related to the use of this type of oxidant when solar energy is the photon source. This is related to increase of the photocatalytic reaction rate which assures proportionally decrease of photo reactor dimensions and dramatically decrease of overall costs.

Hydrogen peroxide is the obvious candidate. It can increase the efficiency of the process at high irradiance and it has been tested with a large number of compounds. Also, it is a very commonly used chemical and, therefore, very cheap. Being an electron acceptor, hydrogen peroxide reacts with conduction band electrons to generate hydroxyl radicals, which are required for the photo mineralization of organic pollutants.

$$
\mathrm{H}_{2} \mathrm{O}_{2}+\mathrm{e}^{-} \rightarrow \mathrm{OH}+\mathrm{HO}^{-}
$$

The following reactions (eqs. 9,10) can also produce $\cdot \mathrm{OH}$ (eq. 10 , which requires $\lambda<300 \mathrm{~nm}$, does not take place with solar radiation).

$$
\begin{aligned}
& \mathrm{H}_{2} \mathrm{O}_{2}+\mathrm{O}_{2}{ }^{\circ-} \rightarrow{ }^{\circ} \mathrm{OH}+\mathrm{HO}^{-}+\mathrm{O}_{2} \\
& \mathrm{H}_{2} \mathrm{O}_{2}+\mathrm{h} \nu \rightarrow 2^{\circ} \mathrm{OH}
\end{aligned}
$$

The effect of this electron acceptor deserves some further comment. In some cases, the addition was found to be beneficial, increasing the degradation rate. The effect depends on the $\mathrm{H}_{2} \mathrm{O}_{2}$ concentration, generally showing an optimum range of concentration. At higher concentrations the improvement starts to decrease. Whereas this beneficial effect can easily be explained in terms of prevention of electron/hole recombination and additional ${ }^{\circ} \mathrm{OH}$ production through reactions 8,9 and 10 , inhibition could be explained in terms of $\mathrm{TiO}_{2}$ surface modification by $\mathrm{H}_{2} \mathrm{O}_{2}$ adsorption, scavenging of photo produced holes (eq.11) and reaction with hydroxyl radicals (eq.12).

$$
\begin{aligned}
& \mathrm{H}_{2} \mathrm{O}_{2}+2 \mathrm{~h}^{+} \rightarrow \mathrm{O}_{2}+2 \mathrm{H}^{+} \\
& \mathrm{H}_{2} \mathrm{O}_{2}+{ }^{\circ} \mathrm{OH} \rightarrow \mathrm{H}_{2} \mathrm{O}+\mathrm{HO}_{2}{ }^{-}
\end{aligned}
$$

The inhibition of adsorption not only depends on the characteristics of the pollutant, but also on the $\mathrm{H}_{2} \mathrm{O}_{2} /$ pollutant concentration ratio.

\section{Metal doped $\mathrm{TiO}_{2}$ assisted photocatalytic degradation of NB under $U$ V-VIS irradiation}

Because of the high energy band gap $(3.2 \mathrm{eV})$, titania can be activated only by ultraviolet (UV) light [36]. In addition, low photo quantum 
efficiency and high recombination of electronhole pairs restrict the titania application. In order to improve optical absorption and photocatalytic activity of $\mathrm{TiO}_{2}$ many attempts have been made [37]. One feasible approach consists of doping oxide semiconductor with metal [38-40].

The degradation of NB from aqueous solution under UV-VIS irradiation using heavy metal doped titania was investigated. Dopant type (Fe, $\mathrm{Ni}, \mathrm{Co}$ ) and their concentration were assessed in relation with pollutant degradation kinetic. Also catalyst dose, $\mathrm{pH}$ and initial $\mathrm{NB}$ concentration influence on degradation efficiency were evaluated in order to set up the optimal working conditions which assure pollutant's advanced degradation.

\section{Photocatalytic activity of metal doped $\mathrm{TiO}_{2}$}

The trapping of electrons can inhibit electron/hole recombination during irradiation, thereby increasing the lifetime of charge carriers. Doping of $\mathrm{TiO}_{2}$ with metal ion introduces a new energy level (dopant impurity level) by the dispersion of metal nanoparticles in titania matrix which acts as electron trap, and also assures enhancement of photocatalytic activity [41]. Since, charges recombination rate depends on dopant type and its concentration, the photocatalytic activity of undoped and $\mathrm{Fe}$, Co, $\mathrm{Ni}$ doped $\mathrm{TiO}_{2}$ in degradation of NB from aqueous solution $\left(2.52 \times 10^{-4} \mathrm{M}\right)$ was investigated [42]. The dopant concentrations, reported to $\mathrm{TiO}_{2}$ were $0.5 ; 1 ; 2 ; 5 \mathrm{wt} . \%$. All experiments were performed at $\mathrm{pH}=7$, with $100 \mathrm{mg} / \mathrm{L}$ catalyst dose and irradiation time between 30$240 \mathrm{~min}$. The efficiency of pollutant degradation was assessed by determination of NB concentration vs. irradiation time in treated samples. Kinetic curves obtained in various working conditions, were linearized by a first order reaction kinetic. From the slope of each equation pseudo-first order rate constants, $\mathrm{k}_{\mathrm{NB}}$ were calculated. Pollutant degradation yields registered at $120 \mathrm{~min}$. irradiation time and $\mathrm{k}_{\mathrm{NB}}$ values for undoped and doped $\mathrm{TiO}_{2}$ are presented in Table 1.

Table 1. NB photocatalytic degradation rate constants and efficiencies of undoped $\mathrm{TiO}_{2}$ and $\mathrm{Fe}, \mathrm{Co}, \mathrm{Ni}$ - doped $\mathrm{TiO}_{2}$ with various dopant content

\begin{tabular}{|c|c|c|c|c|}
\hline Catalyst & Dopant type & [M], wt.\% & $k_{N B}^{I} \times 10^{4}, s^{-1}$ & $\eta^{*}{ }_{\mathrm{NB}}, \%$ \\
\hline Undoped $\mathrm{TiO}_{2}$ & - & - & 1.08 & 54.14 \\
\hline \multirow[t]{12}{*}{ Doped $\mathrm{TiO}_{2}$} & \multirow[t]{4}{*}{$\mathrm{Fe}$} & 0.5 & 2.54 & 84.91 \\
\hline & & 1 & 2.09 & 74.77 \\
\hline & & 2 & 1.76 & 71.77 \\
\hline & & 5 & 1.69 & 67.97 \\
\hline & \multirow[t]{4}{*}{ Co } & 0.5 & 1.48 & 66.07 \\
\hline & & 1 & 2.24 & 81.03 \\
\hline & & 2 & 1.61 & 67.93 \\
\hline & & 5 & 1.12 & 55.51 \\
\hline & \multirow[t]{4}{*}{$\mathrm{Ni}$} & 0.5 & 1.81 & 72.25 \\
\hline & & 1 & 2.19 & 78.49 \\
\hline & & 2 & 1.35 & 61.48 \\
\hline & & 5 & 1.24 & 58.95 \\
\hline
\end{tabular}

*irradiation time $=120 \mathrm{~min}$

Dopant presence in the catalyst matrix assures enhancement of $\mathrm{TiO}_{2}$ photocatalytic activity, the values of pollutant degradation rate constants are higher than those obtained in the presence of undoped titania. At the same dopant content, the rate constants vary as function of dopant type, photocatalytic activity generally decreasing in the following order $\mathrm{Fe}$ - doped $\mathrm{TiO}_{2}>\mathrm{Co}$ doped $\mathrm{TiO}_{2}>\mathrm{Ni}$ - doped $\mathrm{TiO}_{2}$. Various dopants induced different modification on catalyst photoactivity depending on their ionic metal oxidation state and electronic configuration. According with our previous studies, metals are presented in the oxidation state $\mathrm{M}^{3+}$, whose ionic radii are closer to $\mathrm{Ti}^{4+}$ ionic radius in comparison with $\mathrm{M}^{2+}$. This data is confirmed by small differences between unit cell volume registered for undoped titania and 0.5-2wt. \% metal doped $\mathrm{TiO}_{2}$ [35]. Among dopants, $\mathrm{Fe}^{3+}$ ion which presents only 5 electrons on $d$ orbitals is probably more accessible to electron trapping than $\mathrm{Co}^{3+}$ or $\mathrm{Ni}^{3+}$ ions (with 6 and 7 electrons) 
which have less available half-occupied $d$ orbitals. The enhanced photocatalytic activity of $\mathrm{Fe}$ - doped titania compared with $\mathrm{Co}$ or Nidoped titania is revealed by the NB degradation efficiencies obtained at $120 \mathrm{~min}$. irradiation and 2 wt. \% dopant content, which are $71.77 ; 67.93$ and $61.48 \%$, respectively.

Beside dopant type, other parameter which modifies the photocatalytic activity is dopant content. As shown in table1, each dopant presents an optimum concentration level which assures the higher NB degradation efficiency. According to experimental results the optimum concentration for $\mathrm{Fe}$ dopant is $0.5 \mathrm{wt} . \%$ and $1 \mathrm{wt} . \%$ in the case of $\mathrm{Co}$ and $\mathrm{Ni}$ dopants, corresponding $\mathrm{k}_{\mathrm{NB}}$ values being $2.5 \times 10^{-4}$ and $2.2 \times 10^{-4} \mathrm{~s}^{-1}$. Dopant level increase up to optimum concentration positively affected the photocatalytic activity. In the case of $\mathrm{Co}$ and $\mathrm{Ni}$ dopants, enhancement of metal content from 0.5 to $1 \mathrm{wt} . \%$ assures increasing of $\mathrm{k}_{\mathrm{NB}}$ with 45 and $21 \%$, respectively. An opposite behaviour is observed when metal level exceeds optimum content. $\mathrm{k}_{\mathrm{NB}}$ values are decreasing with $18 ; 24$; and $38 \%$ for $\mathrm{Fe}, \mathrm{Co}$, and $\mathrm{Ni}$, respectively, in the case of twice higher content than optimum concentration. In accordance with our results, other authors reported the improved photocatalytic activity of $0.5 \mathrm{wt} \%$ Fe-doped $\mathrm{TiO}_{2}$, which showed drastically increases of charge-carrier lifetime to minutes and even hours beside undoped titania (average lifetime of an electron/hole pair is about 30ns) [43-45].
Doping of $\mathrm{TiO}_{2}$ with metals not only enhanced the separating efficiency of photo-induced electrons and holes, but also increases the visible light absorption due to shortening of band gap. The absorbance spectra for the three catalysts doped with (experimentally set) optimum metal concentrations, were measured at room temperature with a Helios UV/VIS spectrophotometer and comparisons have been made with undoped titania, as shown in Figure 3.

The undoped $\mathrm{TiO}_{2}$ spectrum shows an absorption onset at $390 \mathrm{~nm}$, which is in good agreement with the intrinsic energy band gap of titania at $3.2 \mathrm{eV}$. The absorption spectra for all doped catalysts are shifted to larger wavelength (red shift). The higher absorbance in the range of 400-600nm (visible light region) is observed for $(0.5 \mathrm{wt} . \% \mathrm{Fe})-\mathrm{TiO}_{2}$ catalyst, which confirms its superior photocatalytic activity on NB degradation in aqueous solution under UV-VIS irradiation.

\section{The influence of photocatalyst loading}

In order to determine the effect of catalyst loading, a series of experiments were carried out on $\mathrm{NB}$ solution with $2.52 \times 10^{-4} \mathrm{M}$ content and $\mathrm{pH}=7$, by varying the $(0.5 \mathrm{wt} . \% \mathrm{Fe})-\mathrm{TiO}_{2}$ photo catalyst dose between $50-500 \mathrm{mg} / \mathrm{L}$. From determined pollutant concentration at various irradiation times (60- 240min.) the NB degradation efficiency and rate constant to each applied catalyst dose was calculated.

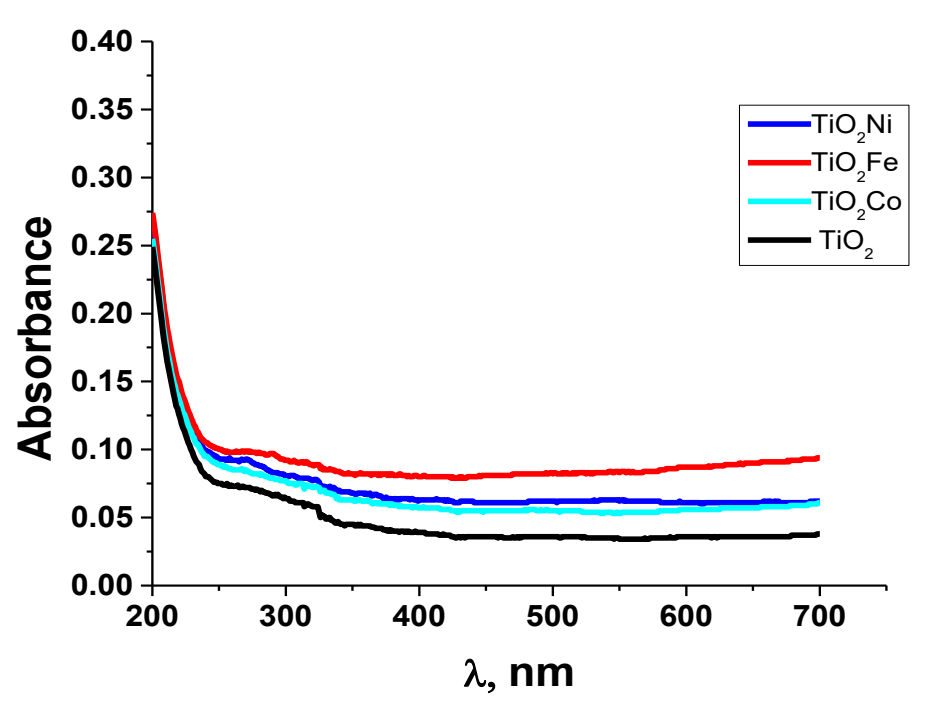

Fig. 3. UV-VIS absorption spectra of heavy metal doped and undoped $\mathrm{TiO}_{2}$ 
The results, presented in table 2 , show that degradation efficiency increases to almost $99 \%$ by increasing the catalyst dose from 50 to 250 $\mathrm{mg} / \mathrm{L}$. Increase of catalyst loading above $250 \mathrm{mg} / \mathrm{L}$, leads to degradation rate decrease. Thus, $79 \%$ degradation efficiency was observed at $500 \mathrm{mg} / \mathrm{L}$ dose. The enhancement of degradation efficiency with catalyst loading was due to the increases in the surface area of the catalyst available for NB adsorption and degradation.

But higher values than optimum catalyst dose $(250 \mathrm{mg} / \mathrm{L})$ also increases solution opacity leading to decreases in the penetration depth of light into suspension and decreasing the degradation rate [46, 47]. In all subsequent experiments the optimum catalyst loading of $250 \mathrm{mg} / \mathrm{L}$ was applied.

\section{The influence of initial $p H$}

The effect of $\mathrm{pH}$ on NB photocatalytic degradation was evaluated over the range 4-10, into solution with $2.52 \times 10^{-4} \mathrm{M}$ pollutant content, at optimum photocatalyst dose $(0.5 \mathrm{wt} \% \mathrm{Fe}$ $\mathrm{TiO}_{2}=250 \mathrm{mg} / \mathrm{L}$ ) for irradiation time between 60-240 min. The NB degradation efficiencies and rate constants for several initial $\mathrm{pH}$ conditions are presented in Table 3. The degradation efficiency increases from 94.4 to $99 \%$ as the $\mathrm{pH}$ value is incremented from 4 to 7 and then decreases under $90 \%$ with the increased value of $\mathrm{pH}$ from 7 to 10 .

Table 2. The influence of photocatalyst loading on NB degradation efficiency and rate constant

\begin{tabular}{|c|c|c|}
\hline Photocatalyst dose, $\mathbf{~ m g} / \mathbf{L}$ & $\mathbf{k N B x}_{\mathbf{N}} \mathbf{4}, \mathbf{s}^{\mathbf{- 1}}$ & $\boldsymbol{\eta}^{*} \mathbf{\text { NB}}, \boldsymbol{\%}$ \\
\hline 50 & 1,35 & 85,71 \\
\hline 100 & 2,50 & 97,22 \\
\hline 250 & 3,05 & 98,80 \\
\hline 500 & 1,08 & 78,96 \\
\hline
\end{tabular}

$*$ irradiation time $=240 \mathrm{~min}$

The $\mathrm{pH}$ of the solution has complex effects on the photocatalytic oxidation reaction, depending on pollutant type and zero-point charge $\left(\mathrm{pH}_{\mathrm{ZPC}}\right)$ of catalyst which in the case of Fe-doped $\mathrm{TiO}_{2}$ is around 7 . When doped catalyst is dispersed in water, the first step is hydration of catalyst surface followed by protonation $(\mathrm{pH}<\mathrm{pH}$ ZPC $)$ or deprotonation $\left(\mathrm{pH}>\mathrm{pH} \mathrm{ZPC}_{\mathrm{Z}}\right)$ depending on solution $\mathrm{pH}$. Thus, the photocatalytic degradation of the ionisable organic compounds will be strongly affected by the $\mathrm{pH}$ due to their interaction with charged catalyst. Less or non-polar compounds as it is the case of NB will be better adsorbed on uncharged catalyst surface and their degradation rate achieve maximum value near the catalyst ZPC [48]. Therefore, the acidic or alkaline $\mathrm{pH}$ does not favour the adsorption of $\mathrm{NB}$ on the $\mathrm{Fe}-\mathrm{TiO}_{2}$ particles.

According to results presented in Table 3, the best $\mathrm{pH}$ value for NB photocatalytic degradation under mentioned condition is 7 , similar data being reported by other authors [49].

Table 3. Effect of $\mathrm{pH}$ on NB degradation efficiency and rate constant

\begin{tabular}{|c|c|c|}
\hline $\mathbf{p H}$ & $\mathbf{k}_{\mathbf{N B}} \mathbf{1 0} \mathbf{1}^{\mathbf{4}}, \mathbf{s}^{-\mathbf{1}}$ & $\boldsymbol{\eta}_{\mathbf{N B}}{ }^{*}, \boldsymbol{\%}$ \\
\hline 4 & 1,98 & 94.44 \\
\hline 7 & 3,05 & 98.80 \\
\hline 10 & 1.47 & 88,04 \\
\hline
\end{tabular}

$*$ irradiation time $=240 \mathrm{~min}$

\section{Kinetics of NB degradation}

Langmuir Hinshelwood (L-H) model is the most commonly expression used to describe the kinetics of the heterogeneous catalytic processes. The Langmuir adsorption model has been applied to organic compounds in aqueous suspension according to the eq.13:

$$
\mathrm{r}_{0}=-\frac{\mathrm{dC}}{\mathrm{dt}}=\frac{\mathrm{k}_{\mathrm{r}} \mathrm{K}_{\text {ads }} \mathrm{C}_{0}}{1+\mathrm{K}_{\text {ads }} \mathrm{C}_{0}}
$$

In which $\mathrm{r}_{0}$ is the NB degradation initial rate, $\mathrm{C}_{0}$ is initial NB concentration, $K_{a d s}$ the equilibrium constant of NB adsorption on catalyst particles and $\mathrm{k}_{\mathrm{r}}$ the reaction rate constant [50,51]. In order to determine the $\mathrm{k}_{\mathrm{r}}$ and $\mathrm{K}_{\mathrm{ads}}$ experiments on $0.5 \% \mathrm{Fe}-\mathrm{TiO}_{2}$ at optimum catalyst dose and 
$\mathrm{pH}=7$, for different initial $\mathrm{NB}$ concentrations between (0.37-8.45) x $10^{-4} \mathrm{M}$ were performed. The $\mathrm{r}_{0}$ values were independently obtained from kinetic curves by the linear feet, using the pseudo-first order kinetics of NB degradation at various initial pollutant concentrations are presented in Figure 4.

Eq. (13) was linearized by its reciprocal expression:

$$
\frac{1}{\mathrm{r}_{0}}=-\frac{1}{\mathrm{k}_{\mathrm{r}}}+\frac{1}{\mathrm{k}_{\mathrm{r}} \mathrm{K}_{\mathrm{ads}} \mathrm{C}_{0}}
$$

only the experimental points during the first 30 min. irradiation. The plot of $1 / \mathrm{r}_{0}=\mathrm{f}\left(1 / \mathrm{C}_{0}\right)$ showed in Figure 5 attests that LangmuirHinshelwood model describes NB photodegradation which occurs at catalyst surface. From the intersection of this straight line with the ordinate results $1 / \mathrm{k}_{\mathrm{r}}$ and the calculated value of the reaction rate is $\mathrm{k}_{\mathrm{r}}=1.23 \mathrm{x}$ $10^{-7} \mathrm{Ms}^{-1}$. The adsorption equilibrium constant $\mathrm{K}_{\mathrm{ads}}=2022 \mathrm{M}^{-1}$ was calculated from the slope.

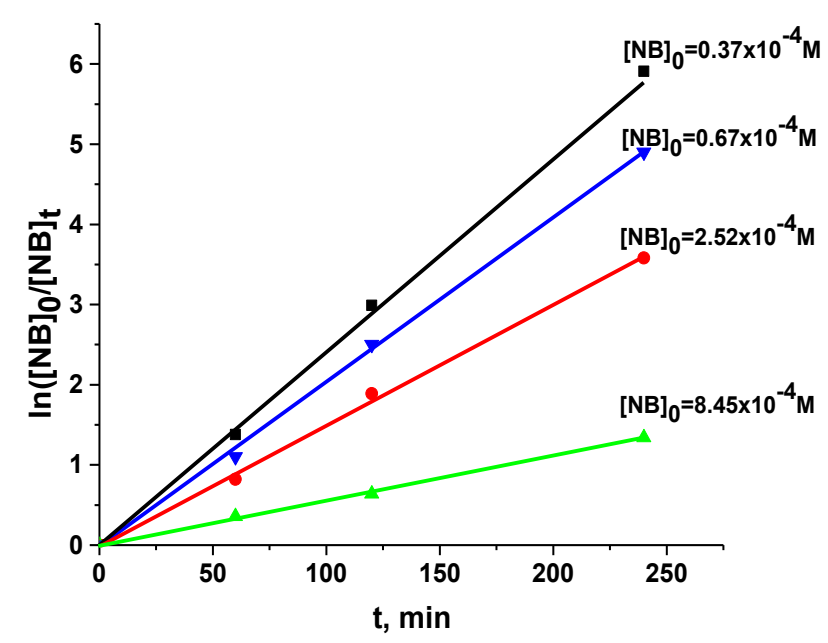

Fig. 4. The pseudo-first order kinetic of NB degradation in different initial concentrations.

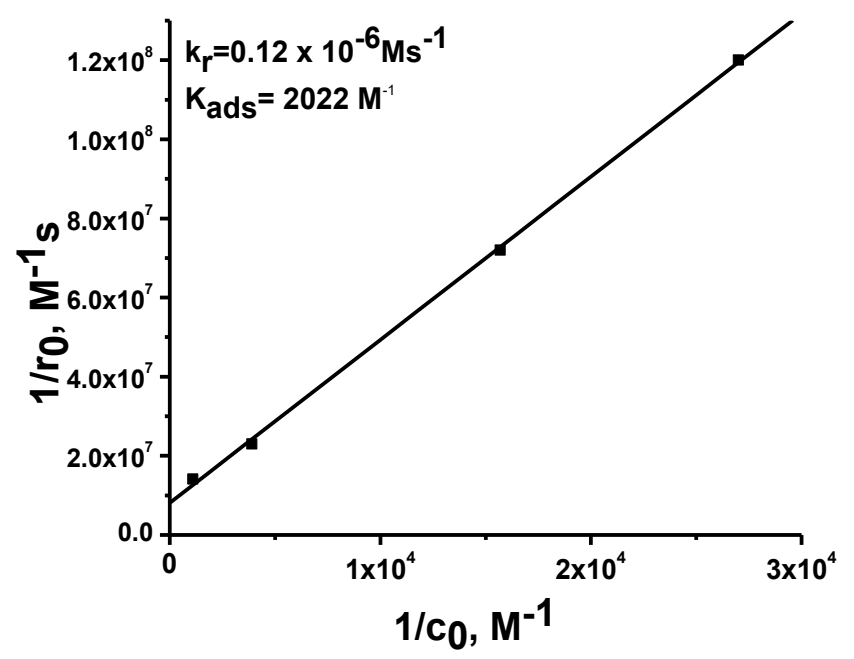

Fig. 5. Linearized eq. of Langmuir-Hinshelwood for NB degradation on $0.5 \% \mathrm{Fe}-\mathrm{TiO}_{2}$

Reactive species involved in photocatalytic degradation of $\mathrm{NB}$ on iron doped $\mathrm{TiO}_{2}$

Trapping experiments were performed in order to identify the main oxidizing species formed during the photocatalytic degradation of NB $\left(2.51 \times 10^{-4} \mathrm{M}\right)$ on $\mathrm{Fe}$ doped $\mathrm{TiO}_{2}$ film catalyst (irradiation $\operatorname{area}=78 \mathrm{~cm}^{2}$ ) [52]. Disodium ethylenediaminetetracetate (EDTA-2Na, 5mM), isopropyl alcohol (IPR, 5mM) and 1,4benzoquinone (BQ, $5 \mathrm{mM}$ ) were utilised as holes $\left(\mathrm{h}^{+}\right)$, hydroxyl radical $\left({ }^{\circ} \mathrm{OH}\right)$ and superoxide radical $\left(\mathrm{O}_{2}{ }^{--}\right)$scavengers, respectively. As is 
presented in Figure 6 the presence of EDTA$2 \mathrm{Na}$ and $\mathrm{BQ}$ do not affected NB degradation, while i-PR drastically decreased the pollutant conversion efficiency. This suggests that hydroxyl radical $\left({ }^{\circ} \mathrm{OH}\right)$ are the main active species involved in NB degradation. Taking into consideration trapping experimental results but also the presence of oxygen vacancy defects $\left(\mathrm{V}_{\mathrm{O}}\right)$ and $\mathrm{Fe}$ species on the catalyst surface we try to propose a possible mechanism of photocatalytic NB degradation on $\mathrm{Fe}$ doped $\mathrm{TiO}_{2}$ under UV-VIS irradiation. It is well known that delay/retardation of charges recombination has a positive effect on photocatalytic activity of $\mathrm{TiO}_{2}$.

One method applied in this respect is trapping of separated charges like electron reduction of oxygen.

In the case of oxygen-deficient $\mathrm{TiO}_{2}$ catalysts, like ours $\mathrm{Fe}$ doped $\mathrm{TiO}_{2}$, the reduction of adsorbed oxygen is inhibited due to $\mathrm{V}_{\mathrm{O}}$ defects states localize at $0.78-1.1 \mathrm{eV}$ below the conduction band (CB) minimum of $\mathrm{TiO}_{2}$ increases the reaction barrier for the single electron reduction of oxygen towards superoxide radical formation. This disadvantage is overcome by the presence of Fe species on the surface of catalyst which served as electrontrapping centers for the multi-electron reduction of adsorbed oxygen. Consequently, upon UVVIS irradiation electrons in the VB of catalyst are first transferred to the $\mathrm{Fe}$ species (redox potential of $\mathrm{Fe}^{3+} / \mathrm{Fe}^{2+}=0.771 \mathrm{~V}$ ), which act as cocatalysts, and subsequently are consumed via the multi-electron oxygen reduction process. The holes left in the VB may react with water and generate ${ }^{\circ} \mathrm{OH}$ radicals that are further involved in pollutant oxidation. The efficient charge carriers' separation achieved by $\mathrm{Fe}$ doped $\mathrm{TiO}_{2}$ assures an enhanced catalyst activity on pollutant degradation under UV-VIS irradiation, due to the synergistic effect of the presence on the catalyst surface of Fe species and oxygen vacancies. This is in accordance with results reported by other authors for Fe species-grafted on $\mathrm{TiO}_{2}$ catalyst applied in the $\beta$-naphtol degradation under visible light irradiation [53].

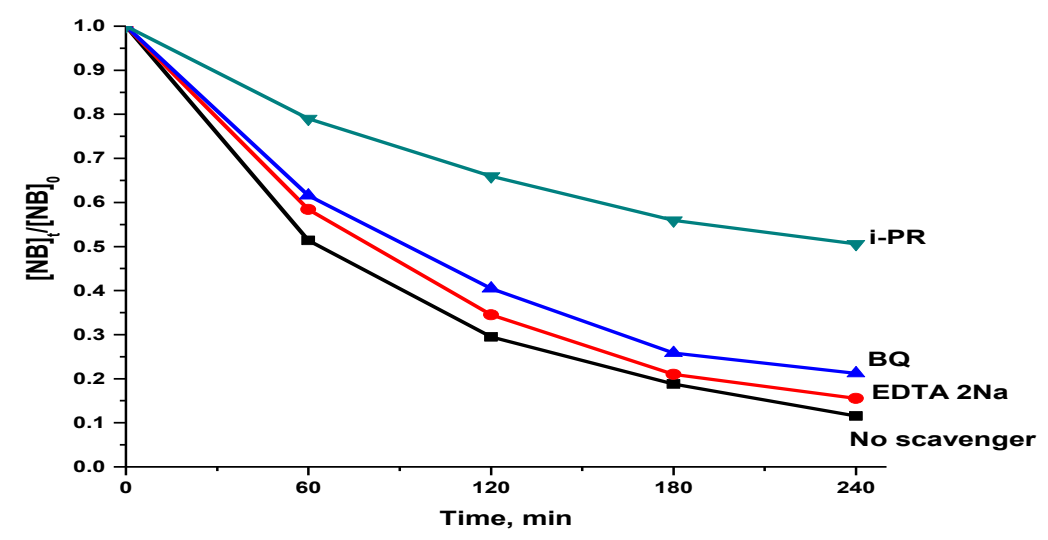

Fig. 6. Photocatalytic degradation of $\mathrm{NB}$ on $0.5 \mathrm{Fe}-\mathrm{TiO}_{2}$ under UV-VIS irradiation with and without addition of oxidizing species scavengers

$\mathrm{TiO}_{2} / \mathrm{H}_{2} \mathrm{O}_{2}$ assisted photocatalytic degradation of CLA under UV-VIS irradiation

The use of inorganic oxidants like hydrogen peroxide, persulphate, chlorate and bromate in $\mathrm{UV} / \mathrm{TiO}_{2}$ system could increase the degradation efficiency either by inhibiting electron-hole pair recombination through scavenging conductionband electrons at the surface of photocatalyst, or offering additional oxygen atom as an electron acceptor to form the superoxide radical ion or reactive radical intermediates [54-56]. We studied photo oxidation of 4-CLA in $\mathrm{UV} / \mathrm{TiO}_{2} / \mathrm{H}_{2} \mathrm{O}_{2}$ usinga wide range of $\mathrm{H}_{2} \mathrm{O}_{2}$ dosage. Degradation pathway of 4-CLA was proposed according to GC-MS identified organic intermediates [57].

Influence of $\mathrm{H}_{2} \mathrm{O}_{2}$ addition

$\mathrm{H}_{2} \mathrm{O}_{2}$, which is an electron acceptor, was added into the solution with 4-CLA content in order to improve pollutant degradation efficiency by enhancing hydroxyl radical concentration and 
also inhibiting electron/hole pair recombination. Thus, experiments were conducted with various concentration of $\mathrm{H}_{2} \mathrm{O}_{2}$ between $1 \times 10^{-4}-1 \times 10^{-2}$ $\mathrm{M}$, at fixed $\mathrm{pH}=4, \mathrm{TiO}_{2}$ dose $150 \mathrm{mg} / \mathrm{L}$ and pollutant concentration $1.42 \times 10^{-3} \mathrm{M}$. The pseudo-first order kinetic equations of pollutant degradation and organic chlorine mineralization without electron acceptor addition, and in the presence of various $\mathrm{H}_{2} \mathrm{O}_{2}$ concentrations were plotted. From the slope of kinetic equations, the rate constants were calculated and values obtained are presented in table 4.
Increase of $\mathrm{H}_{2} \mathrm{O}_{2}$ concentration between $1 \times 10^{-4}$ $-1 \times 10^{-3} \mathrm{M}$ has a positive effect on pollutant degradation; values of $\mathrm{k}_{\mathrm{I}}^{4-\mathrm{CLA}}$ and $\mathrm{k}_{\mathrm{I}}{ }^{\mathrm{Cl}}$ are increasing too. Further addition of $\mathrm{H}_{2} \mathrm{O}_{2}$ does not modify pollutant photocatalytic degradation rate, because, when electron acceptor is over dosed $\left(1 \times 10^{-2} \mathrm{M}\right.$ in the present study), the excess $\mathrm{H}_{2} \mathrm{O}_{2}$ molecules scavenge the valuable hydroxyl radicals and generate a much weaker hydroperoxyl radicals. These ones can further react with the remaining strong hydroxyl radicals to form ineffective oxygen and water.

Table 4. The influence of $\mathrm{H}_{2} \mathrm{O}_{2}$ concentration on thepseudo-first-order rate constants of 4-CLA degradation and organic chlorine mineralization

\begin{tabular}{|c|c|c|}
\hline$\left[\mathbf{H}_{\mathbf{2}} \mathbf{O}_{2}\right] \mathbf{x} \mathbf{1 0}^{\mathbf{4}}, \mathbf{M}$ & $\mathbf{k}_{\mathbf{I}}^{\mathbf{4 - C L A}} \mathbf{x} \mathbf{1 0}^{\mathbf{4}}, \mathbf{s}^{\mathbf{- 1}}$ & $\mathbf{k}_{\mathbf{I}}{ }^{\mathbf{C} \mathbf{}} \mathbf{x} \mathbf{1 0}^{\mathbf{4}}, \mathbf{s}^{\mathbf{- 1}}$ \\
\hline- & 5.50 & 0.88 \\
\hline 1 & 8.71 & 1.52 \\
\hline 10 & 11.94 & 1.97 \\
\hline 100 & 11.32 & 1.96 \\
\hline
\end{tabular}

In addition, the pollutant photocatalytic oxidation could be inhibited when the excess $\mathrm{H}_{2} \mathrm{O}_{2}$ reacts with oxidative holes on catalyst surface, as equations 11,12 show $[54,58]$. Based on presented experimental results it was found that optimum $\mathrm{H}_{2} \mathrm{O}_{2}$ concentration is $1 \times 10^{-3} \mathrm{M}$, which assures after 180 minutes irradiation, $99.99 \%$ pollutant degradation and $88 \%$ organic chlorine mineralization.

The identification of intermediates and 4-CLA degradation mechanism

Several organic intermediates like aniline (A), 4aminophenol (4-AP), 4-chlorophenol (4-CP), 4chloronitrobenzene (4-CNB), 4,4'dichloroazobenzene (DCAB) were identified during 4-CLA photocatalytic degradation in $\mathrm{UV} / \mathrm{TiO}_{2} / \mathrm{H}_{2} \mathrm{O}_{2}$ system, by GS-MS method.

In order to obtain information on subsequent intermediates degradation we compared the specific peak area (directly related with compound concentration) of each GC-MS identified byproduct presented in total chromatogram at different irradiation time and the following aspects have been observed:

- increase of irradiation time leads to 4-CLA and some of its degradation intermediates (4$\mathrm{CP}$, 4-AP, DCAB) concentrations decrease, emphasizing that these are subsequently involved in secondary reactions;

- an opposite behavior is registered in the case of $\mathrm{A}$ and $4-\mathrm{CNB}$ which are accumulated in the system because these are hardly oxidized in the tested working conditions;

- the evolution of DCAB and 4-CNB concentration confirmed that the second one is the degradation product of halogenated diazobenzene derivate;

- after $60 \mathrm{~min}$ of irradiation, 4-AP concentration was almost neglectable compared with 4-CP, suggesting that halogenated derivate is hardly degraded; in addition, 4-CP concentration is almost constant between 60 and $120 \mathrm{~min}$ showing that its generation rate is higher than its subsequently degradation.

Based on previously presented results it was proposed a reaction sequence for the generation of the main intermediates identified during the photocatalytic degradation of 4-CLA as it is presented in Figure 7. 


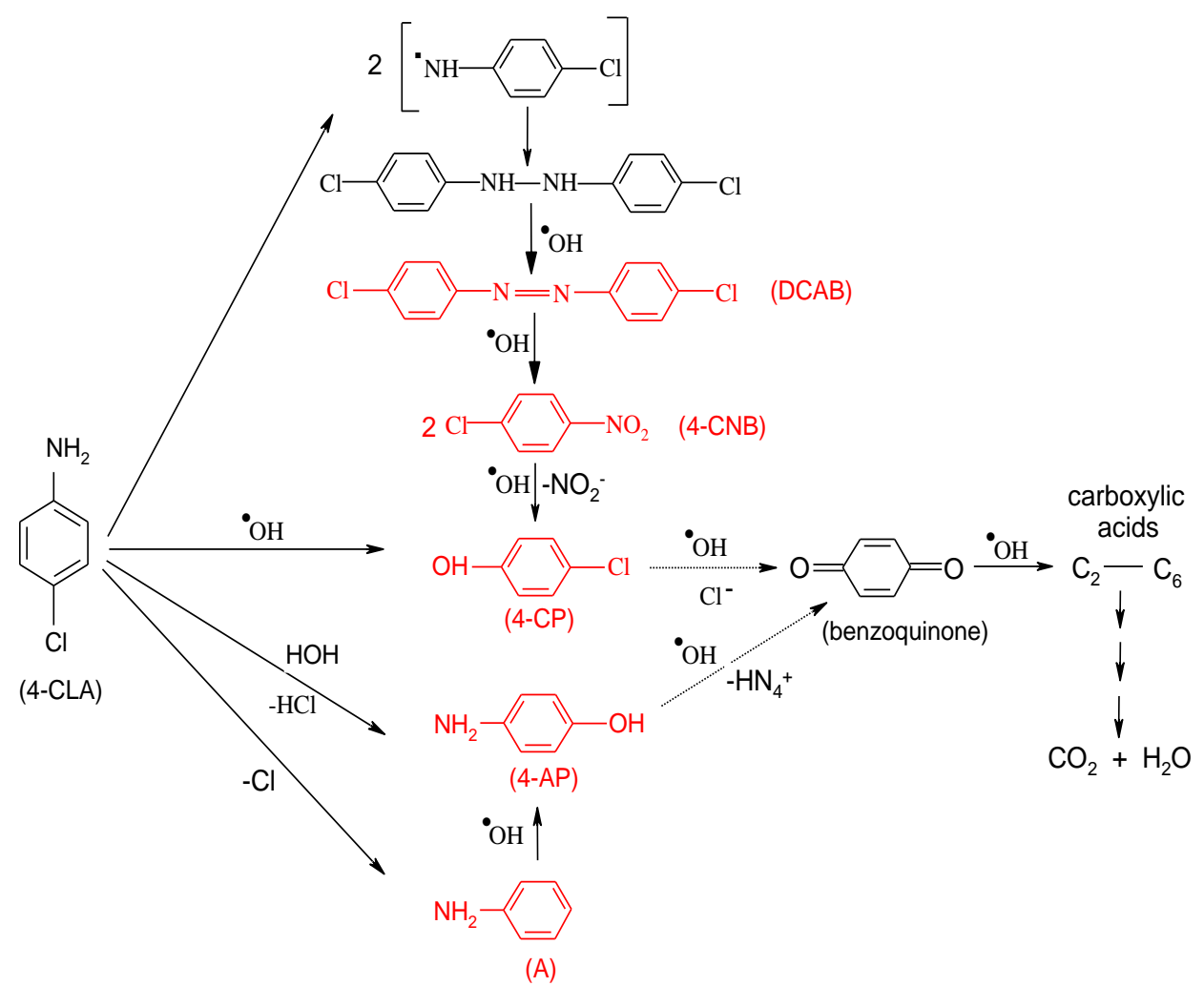

Fig. 7. Proposed photocatalytic degradation pathways of 4-CLA

The proposed mechanism presents four possible pollutant degradation routes:

- $\mathrm{HO}^{\circ}$ radicals attack on target pollutants with replacement of the amino group and $4-\mathrm{CP}$ formation;

- hydrogen abstraction with anilinyl-radical formation, that is subsequently stabilized by dimerization to DCAB; The attack of $\mathrm{HO}^{*}$ radical on diazogroup of DCAB leads to 4$\mathrm{CNB}$ which is further transformed to $4-\mathrm{CP}$ as other researchers also reported [59, 60];

- $\mathrm{Cl}^{-}$release with A formation by a several steps heterolytic mechanism consisting of hydrogen and chloride ions liberation, as $\mathrm{HCl}$, followed by second hydrogen atom elimination with nitrene formation. This one is subsequently rearranged into seven members' carbene, which is converted to aniline $[60,61]$.

- $\mathrm{A}$ is oxidized to 4-AP by $\mathrm{HO}^{\circ}$ radicals addition to the aromatic ring, in accordance with other studies [62]. Since the nature of $\mathrm{HO}^{\circ}$ radical is highly photolytic electrophilic, it preferentially attacks the position with highest electron density of aromatic ring.

In the case of aniline, the hydroxylation take place in para positions with respect to amino group, with lower steric hindrance compared with ortho position; photohydrolisys of 4-CLA with 4-AP formation, is a difficult reaction due to $\mathrm{HO}^{\circ}$ radicals and chlorine have similar electronegativity which inhibiting substitution of halogen atom by hydroxyl radicals;

The secondary intermediates (4-CP, 4-AP) are hydroxilated $[63,64]$ and further oxidized to benzoquinone [65]. This one is subsequently converted to other degradation products like muconic, maleic, fumaric and oxalic acids by ring cleavage under $\mathrm{HO}^{\circ}$ radical attack [66]. The final degradation products include $\mathrm{Cl}^{-}, \mathrm{NH}_{4}{ }^{+}$, $\mathrm{NO}_{3}{ }^{-}$resulted in various steps of proposed degradation routes, as is presented in Fig. 9. The formation of non-chlorinated intermediates like A, 4-AP agrees with experimental results which show $\mathrm{Cl}^{-}$releasing as $\mathrm{HCl}$, during irradiation.

\section{CONCLUSIONS}

$\mathrm{H}_{2} \mathrm{O}_{2}$ assisted photolysis and photocatalysis in various systems like UV-VIS/Fe-TiO ${ }_{2}$ or UVVIS/TiO $/ \quad \mathrm{H}_{2} \mathrm{O}_{2}$ are efficient methods for degradation of chloro and nitroaromatic pollutants. In proper working conditions pollutants advanced degradation $(\eta>99.6 \%)$ is obtained: 
- $\mathrm{UV} / \mathrm{H}_{2} \mathrm{O}_{2}$ system: $[\mathrm{CB}]_{0}=1.8 \times 10^{-3} \mathrm{M}, \mathrm{pH}=$ 7, $\left[\mathrm{H}_{2} \mathrm{O}_{2}\right]=5.4 \times 10^{-2} \mathrm{M}, \mathrm{t}_{\mathrm{irr}}=60 \mathrm{~min}$;

- UV-VIS/Fe-TiO ${ }_{2}$ system: $[\mathrm{NB}]_{0}=0.47 \times 10^{-}$ ${ }^{4} \mathrm{M}, \mathrm{pH}=4,\left[\mathrm{Fe}-\mathrm{TiO}_{2}\right]=250 \mathrm{mg} / \mathrm{L}, \mathrm{t}_{\text {irr }}=240$ min;

- UV-VIS/TiO $/ \mathrm{H}_{2} \mathrm{O}_{2}$ system: $[4 \mathrm{CLA}]_{0}=$ $1.4 \times 10^{-3} \mathrm{M}, \mathrm{pH}=4,\left[\mathrm{TiO}_{2}\right]=200 \mathrm{mg} / \mathrm{L}$, $\left[\mathrm{H}_{2} \mathrm{O}_{2}\right]=1 \times 10^{-3} \mathrm{M}, \mathrm{t}_{\mathrm{irr}}=180 \mathrm{~min}$;

The degradation pathway for any of studied advanced degradation systems includes initial
-OH radicals attack to double bound of aromatic ring with hydroxylated intermediates formation, followed by their oxidation to benzoquinone, which can be subsequently converted into carboxylic acids through ring cleavage. Inorganic ions like $\mathrm{Cl}^{-}, \mathrm{NO}_{3}^{-}, \mathrm{NH}_{4}{ }^{+}$are also formed as mineralization products. Results obtained recommended studied advanced degradation processes as performant alternative treatment methods of wastewater with toxic pollutants content.

\section{REFERENCES}

1. BECERRA-CASTRO, C., LOPES, A. R., VAZ-MOREIRA, I., SILVA, E. F., MANAIA, C. M., NUNES. O. C., Environ. Int., 75, 2015, p. 117.

2. FAURÈS, J.M., HOOGEVEEN, J., WINPENNY, J., STEDUTO, P., BURKE, J., Food and Agriculture Organization of the United Nations (FAO), Rome, 2012.

3. BIXIO, D., THOEYE, C., DE KONING, J., JOKSIMOVIC, D., SAVIC, D., WINTGENS, T., MELIN. T., Desalination, 187, 2006, p. 89.

4. DEBLONDE, T., COSSU-LEGUILlE, C., HARTEMANN P., Int. J. Hyg. Environ. Health, 214, 2011, p. 442.

5. GEISSEN, V., MOL, H., KLUMPP, E., UMLAUF, G., NADAL, M. VAN DER PLOEG, M., VAN DER ZEE, S. E. A. T. M., RITSEMA, C. J., Int. Soil Water Conserv. Res., 3, 2015, p. 57.

6. RASHED, M.N., Organic pollutants - Monitoring, Risk and Treatment.InTech Open, Eds: Rashed, M.N., 2013, p. 174.

7. MACHULEK, A., OLIVEIRA, S.C., OSUGI, M.E., FERREIRA, V.S., QUINA, F.H., DANTAS, R.F., OLIVEIRA, S.L., CASAGRANDE, G.A., ANAISSI, F.J., SILVA, V.O., CAVALCANTE, R.P., GOZZI, F., RAMOS, D.D., DA ROSA, A.P., SANTOS, A.P., DE CASTRO, D.C., NOGUEIRA. J.A., Organic pollutants - Monitoring, Risk and Treatment, InTech Open, Eds: Rashed, M.N., 2013, p.152.

8. FILIPE, O. M. S., MOTA, N., SANTOS, S. A. O., DOMINGUES, M. R. M., SILVESTRE, A. J. D., NEVES, M. G. P. M. S., SIMOES, M. M. Q., SANTOS, E. B. H., J. Hazard. Mater., 323, 2017, p. 250.

9. MALATO, S., MALDONADO, M. I., OLlER, I., ZAPATA. A., Emerging compounds removal from wastewater: natural and solar based treatments, Springer, Eds: Lofrano G., 2012, p. 59-76.

10. MALATO, S., FERNANDEZ-IBANEZ, P., MALDONADO, M. I., BLANCO, J., GERNJAK. W., Catal. Today, 147, 2009, p. 1.

11. ARQUES, A., AMAT.A. M., Emerging compounds removal from wastewater: natural and solar based treatments. Springer, Eds: Lofrano G., 2012, p. 77-91.

12. AHMAD, I., AHMED, S., ANWAR, Z., SHERAZ, M. A., SIKORSKI, M., Int. J. Photoenergy, 2016, 2016, p. 1.

13. MACHULEK, A., QUINA, F.H., GOZZI, F., SILVA, V.O., FRIEDRICH, L.C., MORAES, J.E., F., Organic pollutants ten years after the Stockholm convention - environmental and analytical update, InTech Open, Eds. Puzyn, T., Mostrag-Szlichtyng, A., 2012, p. 271-292.

14. OTURAN, M.A., AARON, J.J., Crit. Rev. Environ. Sci. Technol., 44, 2014, p. 2577.

15. BAUER, R., FALLMANN, H., Res. Chem. Intermed., 23, 1997, p. 341.

16. BAXENDALE, J.H., WILSON, J.A., Trans. Faraday Soc., 53, 1957, p. 344.

17. ANDREOZZI, R., CAPRIO, V., INSOLA, A., MAROTTA, R., Catal. Today, 53, 1999, p. 51. 
18. GLATZ, W.H., BELTRAN, F., TUHKANEN, T., KANG, J.W., Water Pollut. Res. J. Can., 27, 1992, p. 23.

19. LIPCZYNSKA-KOCHANY, E., Water Pollut. Res. J. Can., 27, 1992, p. 97.

20. SUNDSTROM, D.W., WEIR, B.A., KLEI, H.E., Environ. Prog., 8, 1989, p. 6.

21. MOZA, P.M., FYTIANOS, K., SAMANIDOU, V., KORTE, F., Bull. Environ. Contam. Toxicol., 41, 1988, p. 678.

22. WEIR, B.A., SUNDSTROM, D.W., KLEI H.E., Hazard. Waste Hazard., 4, 1987, p. 167.

23. GUITTONNEAU, S., DE LAAT, J., DORE, M., DUGUET, J.P., BONNEL, C., Environ. Technol. Lett., 9, 1988, p. 1115.

24. DIMEGHANI, M., ZAHIR, O. K., J. Environ. Qual., 30, 2001, p. 2063.

25. ANDREOZZI, R., CAPRI, V., D’AMORE, M.G., INSOLA, A., Ozone. Eng. Sci., 14, 1992, p. 177.

26. ANDREOZZI, R., INSOLA, A., CAPRI, V., D’AMORE, M.G., Water Res., 26, 1992, p. 639.

27. BOLTON, J.R., LIPCZYNSKA-KOCHANY, E., Environ. Sci. Technol., 26, 1992, p. 259.

28. ONCESCU, T., NIȚOI, I., OANCEA, P., J. Adv. Oxid. Technol., 11, nr. 1, 2008, p. 149.

29. OLLIS, D.F., HSIAO, C.Y., BUDIMAN, L., LEE, C.L., J. Catal., 88, 1984, p. 89.

30. MASTEN, S.J., DAVIES, S.H. R., Environ. Sci. Technol., 28, 1994, p. 180.

31. OLLIS, D., AL-EKABI, H., Photocatalytic Purification of Water and Air, Elsevier, Eds. Ollis, D., Al-Ekabi, H., New York, 1993, p. 164-168.

32. ZHANG, Y., CRITTENDEN, J.C., HAND, D.W., Chem. Ind., 19, 1994, p. 715.

33. RAJESHWAR, K., J. Appl. Electrochem., 25, 1995, p. 1067.

34. PELIZZETTI, E., CARLIN, V., MINERO, C., GRÄTZEL, M., New J. Chem., 15, 1991, p. 351.

35. MALATO, S., BLANCO, J., RICHTER, C., BRAUN, B., MALDONADO, M. I., Appl. Catal. B, 17, 1998, p. 347.

36. OHNO, T., AKIYOSHI, M., UMEBAYASHI, T., ASAI, K., MITSUI, T., MATSUMURA, M., Appl. Catal. A, 265, 2004, p.115.

37. LEE, S. Y., PARK, S. J., J. Ind. Eng. Chem., 19, 2013, p. 1761.

38. XU, A.W., GAO, Y., LIU, H.Q., J. Catal., 207, 2002, p. 151.

39. ANPO, M., TAKEUCHI, M., J. Catal., 216, 2003, p. 505.

40. SHEN, X.Z., LIU, Z.C., XIE, S.M., GUOUO, J., Hazard, J., Mater., 162, 2009, p.1193.

41. NI, M., LEUNG, M.K.H., LEUNG, D.Y.C., SUMATHY, K., Renew. Sust. Energy Rev., 107, 2007, p. 401.

42. NITOI, I., OANCEA, P., RAILEANU, M., CRISAN, M., CONSTANTIN, L., CRISTEA, I., J. Ind. Eng. Chem., 21, 2015, p. 677.

43. CORDISCHI, D., BURRIESCI，N., DÁlBA，F., PETRERA，M., POlizZETTI, G., SCHIAVELLO, M., Solid State Chem., 56, 1988, p. 182.

44. BALLY, A.R., KOROBEINIKOVA, E.N., SCHMID, P.E., LEVI, F., BUSSY, F., J. Phys. D Appl. Phys., 31, 1998, p. 1149.

45. GENNARI, F.C., PASQUEVICH, D.M., J. Mater. Sci., 33, 1998, p.1571.

46. ROBERT, D., DONGUI, B., WEBER, J.V., J. Photochem. Photobiol., A, 156, 2003, p. 195.

47. DANESHVAR, N., SAlARI, D., KHATAEE, A.R., J. Photochem. Photobiol., A, 162, 2004 , p. 317.

48. SAFARI, M., NIKAZAR, M., DADVAR, M., J. Ind. Eng. Chem., 19, 2013, p.1697.

49. BATHTKANDE, D.S., KAMBLE, S.P., SAWANT, S.B., PANGAKAR, V.G., J. Chem. Eng., 102, 2004, p. 283.

50. GUETTAI, N., AIT AMAE, H., Desalination, 185, 2005, p. 439.

51. EVGHENIDOU, E., PYTIANOS, K., POULIOS, I., Appl. Catal. B, 30, 2005, p. 259.

52. CRISAN, M., MARDARE, D., IANCULESCU, A., DRAGAN, N., NITOI, I., CRISAN, D., VOICESCU, M., TODAN, L., OANCEA, P., ADOMNITEI, C., DOBROMIR, M., GABROVSKA, M., VASILE, B., App. Surf. Sci., 455, 2018, p. 201. 
53. KONG, L., WANG, C., WAN, F., ZHENG, H., ZHANG, X., Appl. Surf. Sci., 396, 2017, p. 26.

54. CHU, W., CHOY, W. K., SO, T.Y., J. Hazard. Mat., 141, 2007, p. 86.

55. CHOY, W.K., CHU, W., Chem. Eng. J., 136, 2008, p.180.

56. WATANABE, N., HORIKOSI, S., KAWABE, H., SUGIE, Y., ZHAO, J., HIDAKA, H., Chemosphere, 52, 2003, p. 851.

57. NITOI, I., OANCEA, P., CRISTEA,I., CONSTANTIN, L., NECHIFOR, GH., J. Photochem. Photobiol., A, 298, 2015, p. 17.

58. WONG, C.C., CHU, W., Chemosphere, 50, 2003, p. 981.

59. KUMAR, A., MATHUR, N., J. Colloid. Interface Sci., 300, 2006, p. 244.

60. ISHIKAWA, S., BABA, K., HANADA, Y., UCHIMURA, Y., KIDO, K., Bull. Environ. Contam. Toxicol., 42, 1989, p. 65.

61. OTHEMEN, K., BOULE, P., J. Photochem. Photobiol. A: Chem., 136, 2000, p. 79.

62. CANLE, M., SANTABALlA, J.A. VULIET, E., J. Photochem. Photobiol., A, 175, 2005, p. 192.

63. ISHIDA, T., ABE, H., NAKAJIMA, A., KAYA, K., Chem. Phys. Lett., 170, 1990, p. 425.

64. DUNNIVANT, F.M., SCHWARZENBACH, R.P., MACALADY, D.L., Environ. Sci. Technol., 26, 1992, p. 2133.

65. BANDARA, J., MIELCZARSKI, J.A., LOPEZ, A., KIWI, J., Appl. Catal. B, 34, 2001, p. 321.

66. WINARO, E.K., GETOFF, N., J. Biosci., 57, 2002, p. 512. 